\title{
Factors influencing the production of Hydrogen by fermentative processes
}

\author{
Liliane Poleto ${ }^{1}$; Flaviane Eva Magrini ${ }^{1}$; Lademir Luiz Beal ${ }^{2}$; Suelen Paesi ${ }^{1}$
}

${ }^{1}$ University of Caxias do Sul, Institute of Biotechnology - Laboratory of Molecular Diagnosis, Caxias do Sul -RS/Brazil 95070-560.Tel+55543218-2149. E-mail poleto@vscomp.com.br, flavimagrini@hotmail.com, sopaesi@ucs.br .

${ }^{2}$ University of Caxias do Sul, Laboratory of Environmental Technologies, Caxias do Sul - RS/ Brazil 95070-560.

Tel +5554 3218-2100 Extension 2792. E-mail llbeal@ucs.br

*Corresponding Author sopaesi@ucs.br

ISSN 2448-0479

\begin{abstract}
Resumo - Fatores que influenciam a produçáo de hidrogênio por processos fermentativos. A crescente preocupação com a substituição de combustíveis fósseis tem incentivado a busca de novas formas de produção de energia limpa. O hidrogênio tem-se destacado como uma forma ideal de energia, pois não contribui para o aumento do efeito estufa além de possuir alto poder calorífico. A produção microbiológica deste gás é um processo que pode se tornar sustentável do ponto de vista social, ambiental e econômico, uma vez que microrganismos isolados do ambiente podem utilizar resíduos provenientes de processos industriais e agrícolas. Diversos microrganismos são descritos na literatura como produtores de hidrogênio, principalmente os gêneros Clostridium e Enterobacter, a partir de diversos tipos de substratos. Porém, diversos fatores e condiçōes fermentativas que irăo direcionar para a rota metabólica de produção de hidrogênio devem ser analisados. Dessa forma, o objetivo deste trabalho é contribuir com o estado da arte, fazendo uma revisão dos recentes trabalhos envolvendo a produçáo microbiológica de hidrogênio e os principais aspectos envolvidos no processo biotecnológico.
\end{abstract}

Palavras chaves - Biohidrogênio. Microrganismo. Fermentação. Substrato. Resíduo. pH. Temperatura.

Abstract - Growing concern about finding suitable replacements for fossil fuels has encouraged the search for new clean energy production processes. Hydrogen has been highlighted as an ideal form of energy because this molecule does not contribute to the greenhouse effect and it possesses a high calorific value. The microbiological production of this gas is a process that can become sustainable from social, environmental and economic points of view once the microorganisms isolated from the environment can use agro-industrial wastes as substrate. Various microorganisms are described in the literature as producers of hydrogen from several types of substrates, especially species from the genera Clostridium and Enterobacter. However, various scientific factors and fermentation operating conditions that will steer the metabolic pathway to the production of hydrogen should be analyzed. The objective of this work is to contribute to the state of the art by reviewing recent studies involving the microbiological production of hydrogen and the main aspects involved in biotechnological process.

Keywords - Biohydrogen. Microorganisms. Fermentation. Substrate. Waste. Ph. Temperature.

Recebido em: 16 de março de 2016

Aprovado em: 22 de abril de 2016

\section{INTRODUCTION}

One of the major challenges in the coming years is will be to find alternative means for producing sustainable and clean energy to replace nonrenewable fossil fuels, such as coal, petroleum and 
natural gas. This need arises because the combustion of these fuels contributes to climate change, especially in relation to the greenhouse effect. In this regard, hydrogen $\left(\mathrm{H}_{2}\right)$ has been highlighted as an ideal form of energy that only forms water when combusted and no pollutants (Equation 1), in addition to being a renewable energy source (LIN et al., 2006; DAS \& VEZIROGLU, 2008).

$$
\text { (1) } 2 \mathrm{H}_{2}+\mathrm{O}_{2} \rightarrow 2 \mathrm{H}_{2} \mathrm{O}
$$

In this way, hydrogen fuel contributes to reducing the levels of atmospheric carbon dioxide $\left(\mathrm{CO}_{2}\right)$, minimizing the problems caused by fossil fuels (MARTINEZ-PEREZ et al., 2007).

Biological processes, such as bacterial photosynthesis (HALLENBECK et al., 2012) and/ or fermentation (TUS'AK et al., 2007; PANDU \& JOSEPH, 2012) produce $\mathrm{H}_{2}$, and these processes are doubly sustainable because fermentable waste can be the substrate for the production of this gas by microorganisms isolated from soil and residual waters, among other environments, to generate a source of safe energy. $\mathrm{H}_{2}$ is still a high cost energy source when compared with other conventional options, but the use of residues in organic production justifies the investments to make the $\mathrm{H}_{2}$ gas more abundant and economically viable (CHONG et al., 2009; SALVI \& SUBRAMANIAN, 2015).

A wide variety of pure or mixed bacterial cultures (MAINTINGUER et al., 2008; QIAN et al., 2011; Lee et al., 2011) have been used for the production of $\mathrm{H}_{2}$ from different substrates, especially species from the genera Clostridium and Enterobacter. These bacteria are commonly used as inocula for the production of $\mathrm{H}_{2}$ due to the significant output of these bacteria $(\mathrm{OH}$ et al., 2009; LAY et al., 2010; PANDU and JOSEPH, 2012). In addition, several factors such as the composition of the culture medium, the temperature, the $\mathrm{pH}$ and the partial pressure are important to improve and enhance this production.

This article reviews the main aspects involved in the organic in vitro production of hydrogen by fermenting microorganisms.

\subsection{Fermentative Hydrogen Production}

Hydrogen is the simplest and most abundant element in the universe, representing 3/4 of existing matter (KALINCI et al., 2009). The interest in hydrogen has increased due to technological advances in fuel cells for cars, homes and businesses, and also the potential of batteries in electronic products and internal combustion engines (DUNN, 2002). However, $\mathrm{H}_{2}$ is not yet available in sufficient quantities and economically feasible production continues to be a challenge. Currently, $95 \%$ of the $\mathrm{H}_{2}$ produced industrially is derived from fossil fuels (TANSKSALE et al., 2010).

$\mathrm{H}_{2}$ can be produced biologically by microorganisms via photosynthesis (MATSUNAGA et al., 2000; YASIN et al., 2013) or dark fermentation using carbohydrates for the formation of this molecule (FANG et al., 2002). Dark fermentation is the fermentative conversion of an organic substrate to $\mathrm{H}_{2}$. This complex process is manifested by a diverse group of bacteria through a series of biochemical reactions. Fermentative microorganisms hydrolyze complex organic polymers to monomers, which are further converted to a mixture of lower molecular weight organic acids and alcohols by the necessary $\mathrm{H}_{2}$ producing acidogenic bacteria (PANDU \& JOSEPH, 2012; GHIMIRE et al.; 2015 ). Sources of fermentative substrate for the production of $\mathrm{H}_{2}$ have been described and tested to determine the efficiencies of these processes, for example, starch (CHEN et al., 2007), cellulose (LEVIN et al., 2006; SIQUEIRA and REGINATTO, 2015) and glucose (HERBERT et al., 2002; ABDALLAH et al., 2016), in addition to industrial and agricultural waste (WANG et al., 2010) such as glycerol (AMARAL et al., 2009; SUHAIMI et al., 2012) and vinasse (FERNANDES, 2008; LAZARO et al., 2014).

To maximize the potential energy contained in the substrates, the fermentative production of $\mathrm{H}_{2}$ can be integrated with the production of $\mathrm{CH}_{4}$, where an acidogenic step precedes a methanogenic process (HAWKES et al., 2007). This potential is due to the high concentration of volatile fatty acids and alcohols contained in the effluent, which represent organic pollutants of high-energy value. Producing power while protecting bodies of water requires a second stage to take advantage of the residual energy contained in the effluent (SHOW et al., 2012). However, this integration is still a challenge because the anaerobic process is quite complex and demands extensive research on the subject. Figure 1 presents a proposal for the processing of substrates to boost energy production. 


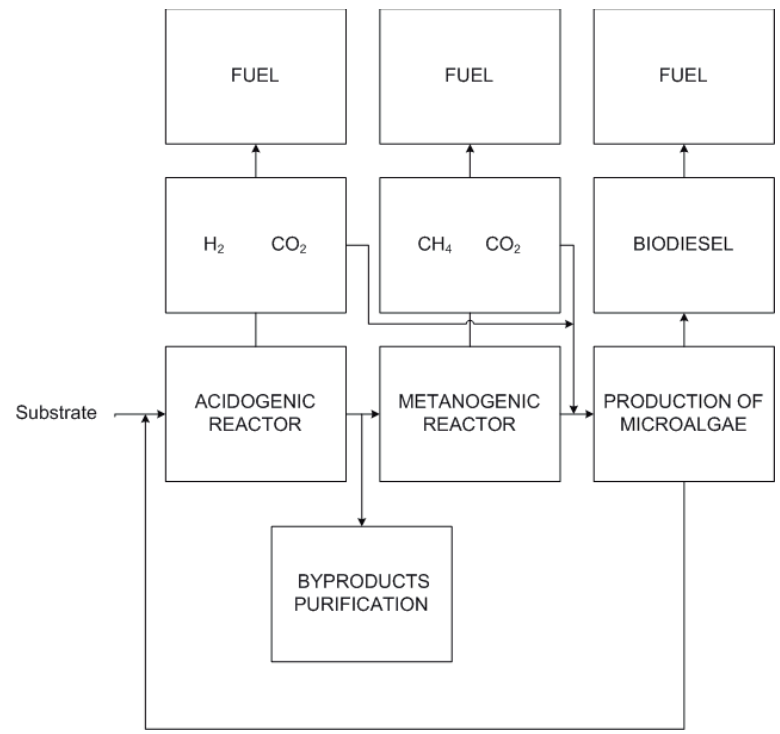

Figure 1: Proposal for the processing of substrates aiming at maximum utilization.

One of the advantages of $\mathrm{H}_{2}$ bioproduction is related to the ability of microorganisms to select a substrate even when this substrate is in a mixture of other compounds. This ability minimizes the need to purify the substrates fed to the process, thereby increasing the spectrum of raw materials that can be used, and reducing the need for chemical treatments (DRAPCHO et al., 2008). In addition, the employment of operating temperature and pressure similar to the environment would an advantage of the relevant microbiological process, providing a favorable energy balance to the process (DAS \& VEZIROGLU, 2008).

A variety of possible advantages of the fermentative production of $\mathrm{H}_{2}$ may be enumerated, such as the low demand for nutrients; the non-necessity of energy for aeration; the ease of constructing the processes compared to aerobic processes; the possibility of producing $\mathrm{H}_{2}$ for $24 \mathrm{~h}$ without the need for light; the great variety of carbon sources that can be used; and the production of valuable metabolites, including butyric acid, acetic acid and various alcohols. The disadvantages are related to the susceptibility of the process to the possible presence of oxygen $\left(\mathrm{O}_{2}\right)$, which is a strong inhibitor; the relatively low-income of $\mathrm{H}_{2}$; the biogas produced by the process is not pure; the technical difficulties associated with later processes aiming at the production of $\mathrm{CH}_{4}$; the increased yield of $\mathrm{H}_{2}$ causes the fermentation to become thermodynamically unfavorable and the presence of by products in addition to $\mathrm{H}_{2}$ (LOGAN et al., 2002; KOTAY \& DAS, 2008; YAZDANI \& GONZALEZ, 2007; DAS \& VEZIROGLU, 2008; WANG \& WAN, 2009; SINHA \& PANDEY, 2011; KUMAR et al., 2016).
However, the fermentative production of $\mathrm{H}_{2}$ depends on a series of operational parameters and physico-chemical conditions that influence the process, as well as the type of substrate, the type of reactor and the presence and concentration of nutrients, in addition to the $\mathrm{pH}$, the temperature and the species of microorganisms used (WANG \& WAN, 2009; XIAO et al., 2010).

\subsection{Main microorganisms involved in fermentative hydrogen production}

This process used bacteria that are compulsory and voluntarily anaerobic. Facultative anaerobes produce a smaller quantity of $\mathrm{H}_{2}$ per mol of substrate, while those microbes that are strictly anaerobic produce a higher amount (DAS \& VEZIROGLU, 2008). Meanwhile, facultative anaerobic microbes are less sensitive to the presence of $\mathrm{O}_{2}$ and have the ability to resume the production of $\mathrm{H}_{2}$ in the case of depleted $\mathrm{O}_{2}$. As a consequence, the facultative anaerobic bacteria are, in general, preferred for the production of $\mathrm{H}_{2}$ by fermentation (OH et al., 2002; DAS \& VEZIROGLU, 2008).

The microorganisms capable of producing $\mathrm{H}_{2}$ can be isolated from natural environments such as soils and sludge treatment stations of domestic and industrial effluents (MAINTINGUER et al., 2015). Many bacteria have been described in the literature as producing $\mathrm{H}_{2}$ from various types of substrates (WANG \& WAN, 2009; KAPDAN \& KARGI, 2006). This process can be performed by pure or mixed cultures of anaerobic fermentative bacteria.

The most common microorganisms used in $\mathrm{H}_{2}$ bioproduction are Clostridium, Enterobacter and Klebsiella (ZHANG et al., 2006; LO et al., 2008; PAN et al., 2008; WANG \& WAN 2009; LAZARO et al., 2014). Bacteria of the genus Clostridium are Grampositive, strictly anaerobic and form endospores of environmental resistance (temperature, alkalinity and acidity) (Song and Dong, 2008). For this reason, bacteria of the genus Clostridium are easily found in a bacterial community (KUO et al., 2011), whereas Enterobacter and Klebsiella, are Gram-negative bacilli and facultative anaerobes (PODSCHUM et al.; 1998; ZHANG et al., 2011). According to Fang et al., (2002), the bacteria of the genus Clostridium represent approximately 65 to $70 \%$ of the total population of bacteria producing $\mathrm{H}_{2}$ that are studied, and these bacteria are classified as proteolytic or saccharolytic, depending on the type of organic material that these 
bacteria ferment. Bacteria from the genus Clostridium proteolytically degrade proteins or amino acids and saccharolytically ferment carbohydrates. A curious fact is that the largest production of $\mathrm{H}_{2}$ reported in the literature was obtained in systems of immobilized cells (granules or biofilms) with the Clostridium genus represented prominently. Among the several Clostridium species, the largest producer was $C$. pasteurianum (LEE et al., 2011).

In relation to the Enterobacteriaceae: because these bacteria are facultative microorganisms, these bacteria are easier to manipulate than other microorganisms because cell growth can occur in the presence of $\mathrm{O}_{2}$ (ZHANG et al., 2011), allowing inhibition of the fermentative process in an atmosphere of $100 \% \mathrm{H}_{2}$ to be investigated (NAKASHIMADA et al., 2002).

\subsection{Pure Cultures}

The capacity for the production of $\mathrm{H}_{2}$ by pure cultures of Clostridium and Enterobacter has been the focus of many recent studies, as shown in Table 1. In addition to these bacteria, other microorganisms are also described in the literature as potential producers of $\mathrm{H}_{2}$ such as the Klebsiella sp., bacteria of the genus Citrobacter, Bacillus (Poleto et al., 2016), Escherichia coli (facultative anaerobic), Pseudomonas, and Thermoanaerobacterium (from extreme environments). Different substrates were used to study the production of $\mathrm{H}_{2}$ from these microbes, including: glucose, glycerol, sucrose, xylose, cellobiose and agro industrial waste. In Table 1, the mode of operation in each batch that is the most widely used in fermentation processes is illustrated, however the maximum rate of production of $\mathrm{H}_{2}, 650 \mathrm{~mL} / \mathrm{g}$ $\mathrm{h}$, was in a continuous reactor for the conversion of glycerol by E. aerogenes (Table 1). However, the rates of hydrogen (Table 1 and 2) produced by the various biohydrogen systems are expressed in different units, making it difficult to assess and compare the rates and amounts of hydrogen synthesized by different biohydrogen technologies (LEVIN et al., 2004).

\subsection{Mixed Cultures}

However, the processes that use mixed cultures are more simple to handle and control, and the organisms in these cultures may even be capable of metabolizing a larger spectrum of substrates, demonstrating, in general, a higher yield of $\mathrm{H}_{2}$ (Table 2) when compared to pure cultures. However, in these cases, attention must be paid to the presence of bacteria both as producers and consumers of $\mathrm{H}_{2}$ in the microbial consortium, which would lead to a decrease in production (WANG \& WAN, 2009). Maintinguer et al., (2008) highlighted the need for pre-treatment of the inoculums to eliminate hydrogenotrophic methanogenic archaea that metabolize $\mathrm{H}_{2}$.

The pre-treatment heating step, together with the control of $\mathrm{pH}$, has been applied for the selection of bacteria capable of producing spores, such as those of the genus Clostridium, which favors the production of $\mathrm{H}_{2}$ because these bacteria are tolerant to adverse environmental conditions and high temperatures (MAINTIGUER et al., 2008; KAWAGOSHI et al., 2005).

Other methods of pre-treatment of the inoculum such as acidic or basic treatment, aeration, freezing followed by thawing and chemical treatments with chloroform, sodium 2-bromoethanesulfonate and iodopropane can also be applied to select microorganisms (WANG \& WAN 2009).

Studies in the literature (Table 2) have used the following carbon sources: purified sucrose, glucose and peptone, as well as sustainable pulp residual forms of manioc, vinasse, molasses, waste food and domestic effluents. Mixed cultures inoculum conducted in batch mode, were more commonly used, and, in general, mixed cultures were more efficient producers of $\mathrm{H}_{2}$ than pure cultures (Table 2).

Microbial identification is essential to determining the composition of the community that effectively ferments substrates to produce $\mathrm{H}_{2}$ and also to assess changes in the structure of mixed communities after the application of certain methods of pre-treatment of the inocula (WANG \& WAN et al., 2008; KIM et al., 2008). Currently, in addition to the classic microbiology, microscopy and cultivation techniques in enriched culture media, other methods are being used for the determination of genus and species. These include qualitative and semiquantitative molecular biology methods, such as PCR, PCR-RFLP, PCR-DGGE, Real Time PCR technique and gene sequencing (OLIVEIRA et al., 2014; MAINTIGUER et al, 2013; 2015).

The use of molecular techniques allows the fluctuations in the microbial communities and hydrogen production to be observed. Small changes in temperature, $\mathrm{pH}$, substrate concentration and other parameters are very influential in shaping the consortium of bacteria that dominates the fermentation. 
Table 1: Results described in the literature for the production of $\mathrm{H}_{2}$ using pure cultures of bacteria from different types of substrates.

\begin{tabular}{|c|c|c|c|c|c|}
\hline Culture & Substrate & Reactor type & $\begin{array}{c}\text { Maximum } \\
\text { hydrogen yield }\end{array}$ & $\begin{array}{c}\text { Rate of } \\
\text { hydrogen } \\
\text { production }\end{array}$ & Reference \\
\hline E. aerogenes & Glycerol & Continuous & $0.89^{\mathrm{a}}$ & $650^{e}$ & Markov et al., (2011) \\
\hline E. aerogenes & Glycerol & Continuous & - & $80^{\mathrm{f}}$ & Ito et al. (2005) \\
\hline E. aerogenes & $\begin{array}{l}\text { Paper and pulp } \\
\text { industry effluent }\end{array}$ & Batch & $2.03^{\mathrm{a}}$ & $225^{\mathrm{g}}$ & $\begin{array}{l}\text { Lakshmidevi \& Muthukumar } \\
\text { (2010) }\end{array}$ \\
\hline E. aerogenes ATCC 35029 & Glycerol & Batch & $0.85 / 0.95^{\mathrm{a}}$ & - & Jitrwung et al., (2011) \\
\hline E. aerogenes & Glycerol & Continuous & $0.84^{a}$ & & Jitrwung et al., (2013) \\
\hline E. cloacae IIT-BT 08 & Glucose & Continuous & $3.1^{\mathrm{a}}$ & $72.1^{\mathrm{h}}$ & Khanna et al., (2011) \\
\hline E. cloacae (WBK3) & Glucose & Batch & $1.8^{\mathrm{a}}$ & $180.74^{\mathrm{i}}$ & Harun et al., (2012) \\
\hline E. cloacae & Glucose & Batch & $3.9^{\mathrm{a}}$ & $0.017^{j}$ & Mandal et al., (2006) \\
\hline E. cloacae & Glucose & - & $3.4^{\mathrm{a}}$ & - & Kumar et al., (2001) \\
\hline C. butyricum & Sugarcane bagasse & Batch & $1.73^{\mathrm{a}}$ & - & Pattra et al., (2008) \\
\hline C. acetobutylicum & Glucose & Batch & $408^{\mathrm{b}}$ & - & Alshiyab et al., (2008a) \\
\hline C. acetobutylicum & Glucose & Batch & $391^{\mathrm{b}}$ & - & Alshiyab et al., (2008b) \\
\hline Clostridium sp. & Molasses & Continuous & - & $390^{k}$ & Lay et al., (2010) \\
\hline Clostridium sp. R1 & Cellobiose & Batch & $2.0^{\mathrm{a}}$ & - & Ho \& Lee (2011) \\
\hline C. perfringens (W11) & Hexose & Batch & $1.53^{\mathrm{a}}$ & - & Wang et al., (2011) \\
\hline Klebsiella pneumonia ECU15 & Glucose & Batch & $2.07^{\mathrm{a}}$ & $482^{\mathrm{i}}$ & Niu et al., (2010) \\
\hline $\begin{array}{c}\text { Klebsiella } \\
\text { pneumoniae DSM2026 }\end{array}$ & Glycerol & Batch & $0.53^{\mathrm{a}}$ & $17.8^{\mathrm{f}}$ & Liu \& Fang (2007) \\
\hline Klebsiella sp. HE1 & Sucrose & Batch & $0.92^{\mathrm{a}}$ & $3.26^{\mathrm{f}}$ & Wu et al., (2008) \\
\hline Klebsiella pneumoniae TR17 & Glycerol & Batch & $0.25^{\mathrm{a}}$ & - & Chookaew et al. (2012) \\
\hline Citrobacter freundii CWBI952 & Sucrose/glucose & Batch & $0.24^{\mathrm{a}}$ & - & Beckers et al., (2010) \\
\hline Citrobacter amalonaticus Y19 & Glucose & Batch & $8.7^{\mathrm{a}}$ & - & Oh et al., (2008) \\
\hline Pseudomonas sp. GZ1 & Residual sludge & Batch & $15.02^{\mathrm{c}}$ & - & Guo et al., (2008) \\
\hline Escherichia coli S3 & Glucose & Batch & - & $16.07^{\mathrm{i}}$ & Junyapoon et al. (2011) \\
\hline Thermotoga neapolitana & Glycerol & Batch & $620^{\mathrm{d}}$ & & Ngos \& Sim (2012) \\
\hline Ethanoligenens harbinense B49 & Glucose & Batch & $2.21^{\mathrm{a}}$ & - & Guo et al., (2009) \\
\hline $\begin{array}{c}\text { Thermoanaerobacterium } \\
\text { aotearoense }\end{array}$ & Glucose/xylose & Batch & $2.71^{\mathrm{a}}$ & - & Li et al., (2010) \\
\hline
\end{tabular}

${ }^{\mathrm{a}} \mathrm{mol} \mathrm{H} \mathrm{mol}^{-1}$ substrate; ${ }^{\mathrm{b}} \mathrm{mL} \mathrm{H}_{2} \mathrm{~g}^{-1}$ glucose; ${ }^{\mathrm{c}} \mathrm{mol} \mathrm{H}_{2} \mathrm{~g}^{-1} \mathrm{TCOD}$; ${ }^{\mathrm{d}} \mathrm{mL} \mathrm{H}_{2} \mathrm{~L}^{-1}$ Glycerol; ${ }^{\mathrm{e}} \mathrm{mLH}_{2} \mathrm{~g}^{-1}$ dry weight h ${ }^{-1}$; $\mathrm{mmol} \mathrm{H}_{2} \mathrm{~L}^{-1} \mathrm{~h}^{-1} ;{ }^{\mathrm{g}} \mathrm{mmol}$ $\mathrm{H}_{2} \mathrm{~g}^{-1}$ cell h $\mathrm{h}^{-1} ;{ }^{\mathrm{h}} \mathrm{mL} \mathrm{H}_{2} \mathrm{~L}^{-1} \mathrm{~h}^{-1} \mathrm{~g}^{-1} ;{ }^{\mathrm{i}} \mathrm{mL} \mathrm{H}_{2} \mathrm{~L}^{-1} \mathrm{~h}^{-1} ;{ }^{\mathrm{j} m o l ~ H} \mathrm{~m}^{-1} ;{ }^{\mathrm{k}} \mathrm{mmol} \mathrm{H}_{2} \mathrm{~L}^{-1} \mathrm{~d}^{-1}$.

The bacterial community that develops in a mixed culture influences the final production of products, such as acids and gases (LAZARO et al., 2014).

\subsection{Main reactions involved in microbiological production of $\mathrm{H}_{2}$}

The fermentative production of $\mathrm{H}_{2}$ is a phenomenon that occurs in anaerobic conditions, where the bacteria degrade organic compounds as a source of energy, especially glucose (KUMAR et al., 2016). Because fermentation is less energetically efficient than aerobic oxidation, these microorganisms develop much more slowly than in an aerobic process.

The stoichiometry of the fermentation and oxidation reactions is vast and complex. These reactions rely on association syntrophy, i.e., when a species degrades a substrate and the generated product, is used by another species. The three main steps of the process are the anaerobic hydrolysis of organic matter, acidogenesis and methanogenesis (LEVIN et al., 2004; Valdez-Vazquez \& POGGI-VARALDO, 2009; GRADY et al., 2011). Before organic matter can be metabolized, the organic compound needs to be hydrolyzed, and the macromolecules must be reduced in size to facilitate transport through the cell membrane. A carbohydrate, for example, should be reduced until this sugar becomes a disaccharide (SAWYER et al., 1994). The reactions responsible for the hydrolysis and reduction in size of organic macromolecules are usually hydrolytic and are catalyzed by extracellular enzymes (amylase, cellulase, protease) produced by bacteria. 
Table 2: Results described in the literature for the production of $\mathrm{H}_{2}$ using mixed cultures inoculum and different types of substrates.

\begin{tabular}{|c|c|c|c|c|}
\hline Substrate & Reactor type & Maximum hydrogen yield & $\begin{array}{l}\text { Rate of hydrogen } \\
\text { production }\end{array}$ & Reference \\
\hline Peptone / glucose & Batch & $6.4^{\mathrm{a}}$ & - & Bai et al., (2004) \\
\hline Starch & Batch & $0.99^{\mathrm{b}}$ & - & Ding et al., ( 2007) \\
\hline Glucose & Batch & $1.87^{\mathrm{b}}$ & - & $\begin{array}{l}\text { Kraemer \& Bagley } \\
\qquad(2008 \mathrm{~b})\end{array}$ \\
\hline $\begin{array}{l}\text { Glucose/Sucrose /starch } \\
\text { potato/ Lactate/cellulose }\end{array}$ & Batch & $0.92 / 1.8 / 0.59 / 0.01 / 0.003^{b}$ & - & Logan et al., (2002) \\
\hline Glycerol & Batch & $34.2^{\mathrm{c}}$ & - & Rossi et al., (2011) \\
\hline Xylose & Batch & $2,25^{\mathrm{b}}$ & & Lin \& Chen (2007) \\
\hline Dairy wastewater & Batch & $0.0317^{\mathrm{a}}$ & - & Mohan et al., (2008) \\
\hline Sucrose & Batch & $5.64^{a}$ & - & Zhu and Beland (2006) \\
\hline Glycerol and sludge & Batch & - & $1.37^{\mathrm{h}}$ & $\begin{array}{c}\text { Sittijunda \& Reungsang } \\
\text { (2012) }\end{array}$ \\
\hline Molasses & Continuous & - & $10,74^{\mathrm{h}}$ & Han a et al., (2011) \\
\hline Food waste & Continuous & $0.87^{\mathrm{b}}$ & - & Kin \& Shin (2008) \\
\hline Glucose & Continuous & $2.0^{\mathrm{b}}$ & - & $\begin{array}{l}\text { Kraemer and Bagley } \\
\text { (2008a) }\end{array}$ \\
\hline Sucrose & Batch & $131.9^{\mathrm{d}}$ & - & Lee et al., (2001) \\
\hline Starch & Batch & $9.47^{\mathrm{e}}$ & - & Lee et al., (2008) \\
\hline Sucrose & Batch & - & $13.3^{\mathrm{i}}$ & Lin \& Lay (2004) \\
\hline Sucrose & Batch & $3.43^{\mathrm{f}}$ & - & Lin \& Lay (2005) \\
\hline Glucose & Continuous & $1.15^{\mathrm{f}}$ & - & Lin \& Chang (2004) \\
\hline Sucrose & Continuous & $4.22^{\mathrm{f}}$ & $128.13^{j}$ & Lima \& Zaiat (2012) \\
\hline Sucrose & Continuous & $280^{\mathrm{d}}$ & $13^{\mathrm{k}}$ & Fang et al., (2002) \\
\hline Sucrose & Batch & $10.16^{\mathrm{f}}$ & - & Sun et al., (2010) \\
\hline Glycerol & Batch & $1.1 \pm 0.1^{\mathrm{f}}$ & - & Mangayil et al., (2012) \\
\hline Sucrose/starch & Batch & $214 / 125^{g}$ & - & Khanal et al., (2004) \\
\hline Pulp of cassava & Batch & $345.8^{\mathrm{g}}$ & $3.385^{\mathrm{m}}$ & Phowan et al., (2010) \\
\hline Sugarcane vinasse & Batch & $2.31^{\mathrm{a}}$ & & Lazaro et al., (2014) \\
\hline
\end{tabular}

${ }^{\mathrm{a}} \mathrm{mmol} \mathrm{H} \mathrm{gg}^{-1} \mathrm{COD} ;{ }^{\mathrm{b}} \mathrm{mol} \mathrm{H} 2 \mathrm{~mol}^{-1}$; ${ }^{\mathrm{c}} \% \mathrm{~mol} ;{ }^{\mathrm{d}} \mathrm{mL} \mathrm{H} 2 \mathrm{~g}^{-1} ;{ }^{\mathrm{e}} \mathrm{mmol} \mathrm{H}_{2} \mathrm{~g}^{-1} ;{ }^{\mathrm{f}} \mathrm{molH}_{2} \mathrm{~mol}^{-1}$ substrate; ${ }^{\mathrm{g}} \mathrm{mL} \mathrm{H}_{2} \mathrm{~g}-{ }^{1} \mathrm{COD}{ }^{\mathrm{h}} \mathrm{mmol} \mathrm{H}_{2} \mathrm{~L}^{-1} \mathrm{~h}$; ${ }^{\mathrm{i}} \mathrm{mL}^{-1} \mathrm{~h} ;{ }^{j} \mathrm{~mL} \mathrm{H}_{2} \mathrm{~h}^{-1} \mathrm{~L}^{-1} ;{ }^{\mathrm{k}} \mathrm{LH}_{2} \mathrm{~L}^{-1}$ day; ${ }^{1} \mathrm{mLH}_{2} \mathrm{~L}^{-1}$ day

In acidogenesis, amino acids and sugars are degraded by fermentative reactions in which organic compounds serve as both donors and acceptors of electrons. Then, a simple sugar, for example, is converted to pyruvic acid and then pyruvic acid is converted to various products.

The formation of these products is dependent on the species involved in the fermentation. The main products of this step are intermediate products, such as, propionic acid (Equation 3)and butyric acid (Equation 4), in addition to the formation of direct precursors of methane, acetic acid (Equation 5) and hydrogen. Depending on the microbial species involved, acetone (Equation 6) and ethanol (Equation 7) can also be formed.

In relation to the output of the different metabolic routes, when acetic acid is the end product, a theoretical maximum yield of 4 mols of $\mathrm{H}_{2}$ per mol of glucose is obtained. When butyric acid is the end product, a theoretical maximum yield of 2 mols of $\mathrm{H}_{2}$ per mol of glucose is obtained. The yield of $\mathrm{H}_{2}$ is even smaller when more reduced organic compounds, such as lactic acid and ethanol, are produced.

(3) $\mathrm{C}_{6} \mathrm{H}_{12} \mathrm{O}_{6}+2 \mathrm{H}_{2} \mathrm{O} \rightarrow \mathrm{CH}_{3} \mathrm{CH}_{2} \mathrm{COOH}+2 \mathrm{H}_{2} \mathrm{O}$

(4) $\mathrm{C}_{6} \mathrm{H}_{12} \mathrm{O}_{6}+2 \mathrm{H}_{2} \mathrm{O} \rightarrow \mathrm{CH}_{3} \mathrm{CH}_{2} \mathrm{CH}_{2} \mathrm{COOH}+2 \mathrm{H}_{2}+2 \mathrm{CO}_{2}$

(5) $\mathrm{C}_{6} \mathrm{H}_{12} \mathrm{O}_{6}+2 \mathrm{H}_{2} \mathrm{O} \rightarrow 2 \mathrm{CH}_{3} \mathrm{COOH}+4 \mathrm{H}_{2}+2 \mathrm{CO}_{2}$

(6) $\mathrm{C}_{6} \mathrm{H}_{12} \mathrm{O}_{6}+2 \mathrm{H}_{2} \mathrm{O} \rightarrow \mathrm{CH}_{3} \mathrm{COCH}_{3}+3 \mathrm{CO}_{2}+4 \mathrm{H}_{2}$

(7) $\mathrm{C}_{6} \mathrm{H}_{12} \mathrm{O}_{6} \rightarrow 2 \mathrm{CH}_{3} \mathrm{CH}_{2} \mathrm{OH}+2 \mathrm{CO}_{2}$

One of the extensively studied species of Clostridium, C. butyricum (PATTRA, 2008; SAINTAMANS, 2001; SOLOMON et al., 1995), produces butyric acid as the main product of its fermentation process, along with the $\mathrm{CO}_{2}$ and $\mathrm{H}_{2}$. This metabolic pathway is found in approximately $50 \%$ of the 
microorganisms of the genus Clostridium (KHANAL et al., 2004). The species of this genus produce $\mathrm{H}_{2}$ during the exponential growth phase of cell growth because reaching the stationary phase requires changes in cellular metabolism, moving from the production of $\mathrm{H}_{2}$ to the production of other compounds (CHONG et al., 2009). However, the predominance of the two metabolic pathways that generate acetic acid and butyric acid depend not only on the type of microorganism but also on the growth conditions. For example, the $\mathrm{pH}$, mixing process, hydraulic retention time, rate of organic load, partial pressure of $\mathrm{H}_{2}$ inside the reactor and nutrients all influence this relationship (KHANAL et al., 2004).

However, the production of $\mathrm{H}_{2}$ by fermentation reactions is small. The greater part of the production of $\mathrm{H}_{2}$ comes from the oxidation of long chain fatty acids (Equation 8) and volatile acids, such as propionic acid (Equation 9), butyric acid (Equation 10) and acetic acid, in a process called anaerobic oxidation.

(9)

$$
\text { (10) } \mathrm{CH}_{3} \mathrm{CH}_{2} \mathrm{CH}_{2} \mathrm{COOH}+2 \mathrm{H}_{2} \mathrm{O} \rightarrow 2 \mathrm{CH}_{3} \mathrm{COOH}+2 \mathrm{H}_{2}
$$

Equation 11 demonstrates that some $\mathrm{H}_{2}$ can be combined with $\mathrm{CO}_{2}$ by homoacetogenic bacteria to form acetic acid, representing a reduction in the efficiency of the production of $\mathrm{H}_{2}$ (KRAEMER and BAGLEY, 2007b).

$$
\text { (11) } 4 \mathrm{H}_{2}+2 \mathrm{HCO}_{3}^{-}+\mathrm{H}^{+} \rightarrow \mathrm{CH}_{3} \mathrm{COO}^{-}+4 \mathrm{H}_{2} \mathrm{O}
$$

In the last step of the fermentation process, methanogenesis, the acetic acid and $\mathrm{H}_{2}$ are converted by methanogenic acetoclastic and hydrogenotrophic bacteria to $\mathrm{CH}_{4}$ and $\mathrm{CO}_{2}$. Equation 12 shows the conversion to $\mathrm{CH}_{4}$ by hydrogenotrophic bacteria.

$$
4 \mathrm{H}_{2}+\mathrm{HCO}_{3}^{-}+\mathrm{H}^{+} \rightarrow \mathrm{CH}_{4}+3 \mathrm{H}_{2} \mathrm{O}
$$

When sulfates and nitrates are present, sulfateand nitrate-reducing bacteria are able to use the $\mathrm{H}_{2}$ as a donor of electrons generating sulfides and ammonia, respectively. Therefore, the $\mathrm{H}_{2}$ produced in an anaerobic process can be consumed by archeas methanogenic bacteria, homoacetogenics bacteria
(Equation 13) and sulfur- (Equation 14) and nitratereducing (Equation 15) bacteria.

$$
\begin{aligned}
& \text { (13) } 4 \mathrm{H}_{2}+2 \mathrm{HCO}_{3}^{-}+\mathrm{H}^{+} \rightarrow \mathrm{CH}_{3} \mathrm{COO}^{-}+4 \mathrm{H}_{2} \mathrm{O} \\
& \text { (14) } 4 \mathrm{H}_{2}+\mathrm{SO}_{4}^{-2} \rightarrow \mathrm{HS}^{-}+3 \mathrm{H}_{2} \mathrm{O}+\mathrm{OH}^{-} \\
& \text {(15) } 4 \mathrm{H}_{2}+\mathrm{NO}_{3}^{-}+2 \mathrm{H}^{+} \rightarrow \mathrm{NH}_{4}^{+}+3 \mathrm{H}_{2} \mathrm{O}
\end{aligned}
$$

To increase the efficiency of the production of $\mathrm{H}_{2}$, several studies describe the bioengineering of strains of Enterobacter aerogenes to genetically manipulate specific metabolic pathways (LU et al., 2009; ZHAO et al., 2009; LU et al., 2010; 2011) to direct metabolism towards only the production of $\mathrm{H}_{2}$, and, thereby, increase the productivity of these modified organisms. Additionally, the addition of formate to the glucose culture (KUROKAWA and TANISHO, 2005), the employment of substrates with different states of oxidation, or even the addition of external nicotinamide adenine dinucleotide in reduced form (NADH) (ZHANG et al., 2009; ZHANG et al., 2011), can also increase production of $\mathrm{H}_{2}$ by cell cultures.

\subsection{Parameters for the production of $\mathbf{H}_{2}$ 1.6.1 Substrates}

Proteins and carbohydrates can be used as substrates for the production of $\mathrm{H}_{2}$, although the latter offer higher yields. Carbohydrates represent the preferred substrate of bacteria in fermentation processes aiming at the production of $\mathrm{H}_{2}$. However, studies indicate that a combination of proteins and carbohydrates results in greater production of $\mathrm{H}_{2}$. According to DING et al. (2008), the presence of protein among the substrates not only increases the ability of the process to neutralize volatile acids due to the alkalinity of the process but also increases the production of $\mathrm{H}_{2}$ by offering readily available organic nitrogen in the form of soluble protein and amino acids to the microorganisms (GHIMIRE et al., 2016).

Currently, the cost of $\mathrm{H}_{2}$ generated from biological processes is very high. Several novel approaches have been proposed to the use of agroindustrial waste as substrate. As media composition significantly affects the production of organic acids and hydrogen by dark fermentation, the composition of complex media plays an important role (SYDNEY et al., 2014). Complex carbon sources, such as molasses (LAY et al., (2010), paper and pulp industry effluent (LAKSHMIDEVI \& MUTHUKUMAR, 
2010), food waste (KIN \& SHIN, 2008), dairy waste (MOHAN et al., 2008), pulp of cassava (PHOWAN et al., 2010), glycerol waste (ITO et al., 2005), sugarcane bagasse (PATTRA et al., 2008), sugarcane vinasse (LAZARO et al., 2014) and others proved to be susceptible for dark fermentation.

Various authors differ with respect to the concentration of substrate to apply in anaerobic reactors to maximize the production of $\mathrm{H}_{2}$ (WANG and WAN, 2009). According to LIN et al. (2012), there is no set optimal substrate concentration can be applied in anaerobic reactors, although in the literature several studies highlight the effects of the concentration of substrates and operating conditions on fermentative process. The majority of studies relate the organic production of $\mathrm{H}_{2}$ from effluents and solid wastes at concentrations lower than $40 \mathrm{~g}$ COD (chemical oxygen demand)/L. Higher production of $\mathrm{H}_{2}$ has also been obtained at low substrate concentrations (LIN et al., 2012).

The relationship between food/microorganism is also a factor that needs to be considered in the production of $\mathrm{H}_{2}$ because this parameter allows the optimal concentration of inoculum and substrate present in a reactor to be determined. As an example, using a mixed culture in the degradation of sucrose, CHEN et al. (2006) obtained a maximum yield of $\mathrm{H}_{2}$ for $7.3 \mathrm{~g} \mathrm{COD} / \mathrm{g}$ VSS (volatile suspended solids). Maximum yields were obtained when degraded waste from food and powdered milk were used at $7.8 \mathrm{~g}$ $\mathrm{COD} / \mathrm{g}$ VSS and $14.7 \mathrm{~g} \mathrm{COD/g} \mathrm{VSS,} \mathrm{respectively.}$

\subsubsection{Nutritional Solution}

Bacteria can develop using very simple substrates, such as sugars; however, some essential elements must be present in the form of ions or inorganic salts.

Among the main nutrients that stands out are nitrogen and sulfur, due to the importance of these elements in bacterial growth. Phosphorus is also a very important element, however, only $1 / 5$ as much phosphorous is required by bacteria compared to nitrogen (for example, $0.2 \mathrm{~kg}$ of phosphorus for each $\mathrm{kg}$ of nitrogen).

In addition to nutrients, trace elements (micronutrients) are also required for cellular metabolism. Many of these trace elements assist in enzymatic function or in other physiological capabilities. Among these micronutrients, Ca, Co, $\mathrm{Cu}, \mathrm{Fe}, \mathrm{Mg}, \mathrm{K}, \mathrm{Mn}$, and $\mathrm{Zn}$ are prominent. For some bacteria, such as nitrogen-fixing bacteria, molybdenum is also necessary. Lastly, nickel is required by methanogenic bacteria (SAWYER et al., 1994).

Several studies have suggested the employment of a nutrient solution for the production of $\mathrm{H}_{2}$; however, various combinations and concentrations are used. Clearly, successful fermentation processes depend on certain conditions, such as the substrate and consortium of bacteria used in the culture medium. PEIXOTO (2008) analyzed the production of $\mathrm{H}_{2}$ in an anaerobic fixed bed reactor using the effluent from the refrigerant industry as substrate, and obtained a greater reduction in COD $(23.1 \%)$ and a maximum production of $\mathrm{H}_{2}\left(29.4 \mathrm{~mL} / \mathrm{min}^{-}\right.$ $\left.{ }^{1}\right)$ in an experiment conducted without the addition of nutrients. The author concluded that for the effluent used in the study, the addition of a medium containing macro and micronutrients was not required. On the contrary, according to the author the nutrient solution hampered the performance of the system.

In contrast, ITO et al. (2005) demonstrated that without the addition of a nutrient solution, the substrate was not completely degraded after $48 \mathrm{~h}$ and bacterial growth was not observed in this period for the conversion of glycerol to $\mathrm{H}_{2}$ in batch mode operation and using the bacterium E. aerogenes. In the study, the degradation of glycerol required some additional nutrients. With the addition of a nutrient solution to the process, the glycerol was entirely consumed after $24 \mathrm{~h}$, and a $\mathrm{H}_{2}$ yield of $0.89 \mathrm{~mol} \mathrm{H}_{2}$ / mol of glycerol was obtained.

According to some studies, the compounds $\mathrm{Mg}, \mathrm{Na}, \mathrm{Zn}$, and Fe are the trace elements that most affect the production of $\mathrm{H}_{2}$, the first being the most important of all. In studies by Lin and Lay (2005), the concentrations $\left(\mathrm{mg} / \mathrm{dm}^{-3}\right)$ of these nutrients that led to maximum production $\mathrm{H}_{2}$ were: $120 \mathrm{MgCl}_{2}$. $6 \mathrm{H}_{2} \mathrm{O} ; 1000 \mathrm{NaCl} ; 0.5 \mathrm{ZnCl}_{2}$ and $3 \mathrm{FeSO}_{4} \cdot 7 \mathrm{H}_{2} \mathrm{O}$. A 30\% increase or decrease in magnesium resulted in a $40 \%$ reduction in the hydrogen production, while an increase or reduction of this same percentage for iron caused a $20 \%$ reduction in the production of hydrogen (LIN and LAY, 2005).

On the contrary, ALSHIYAB et al. (2008a) observed an inhibition of the production of $\mathrm{H}_{2}$ when magnesium in the form of $\mathrm{MgSO}_{4} \cdot 7 \mathrm{H}_{2} \mathrm{O}$ was added as a nutrient to a fermentative process in batch cultures containing $5 \mathrm{~g} / \mathrm{L}$ of glucose. Concentrations ranging from 0 to $1000 \mathrm{mg} / \mathrm{L} \mathrm{MgSO}_{4} \cdot 7 \mathrm{H}_{2} \mathrm{O}$ 
were investigated as the concentration of biomass was gradually increased in the reactors, reaching a maximum of $1466 \mathrm{~g} / \mathrm{L}$, but no significant increase in the production of $\mathrm{H}_{2}$ was observed.

In the degradation of glycerol using the bacterium Enterobacter aerogenes, Jitrwung et al., (2011) suggested replacing the commonly used ammonium sulfate by ammonium nitrate and reducing the concentrations of some salts, such as $\mathrm{FeSO}_{4}$ and $\mathrm{Na}_{2} \mathrm{HPO}_{4}$. The results showed a higher yield of $\mathrm{H}_{2}$ compared to a study previously reported in the literature and even reduced the costs by $76 \%$ with the replacement and reduction of these reagents.

Specifically for nitrogen, studies in the literature emphasize the concentration of ammoniacal nitrogen as source for the production of $\mathrm{H}_{2}$. We recommend new approaches to study the influence of nitrogen on the production of $\mathrm{H}_{2}$, evaluating the implementation of other forms of this element in the fermentation process. A disagreement exists regarding the an optimal concentration of ammoniacal nitrogen, varying from $0.01 \mathrm{~g} \mathrm{~N} / \mathrm{L}$ up to $7.0 \mathrm{~g} \mathrm{~N} / \mathrm{L}$ (WANG $\&$ WAN, 2009).

The metal ion $\mathrm{Fe}^{2+}$ is another important nutrient in the production of $\mathrm{H}_{2}$, and this ion is essential in the formation of hydrogenase and other enzymes, and also determines the production of 1,3-propanediol, which is not desired in processes aiming at the production of $\mathrm{H}_{2}$ (DABROCK et al., 1992; LEE et al., 2001; ALSHIYAB et al., 2008a).

The influence of phosphates and carbonates are also important to the production of $\mathrm{H}_{2}$. These compounds are used as nutrients in biological processes and also provide buffering capacity that helps to control the variation in $\mathrm{pH}$ throughout the process. LIN \& LAY (2004) evaluated the effects of the concentration of carbonates and phosphates such as $\mathrm{NH}_{4} \mathrm{HCO}_{3}, \mathrm{NaHCO}_{3}, \mathrm{Na}_{2} \mathrm{CO}_{3}, \mathrm{~K}_{2} \mathrm{HPO}_{4}$, $\mathrm{KH}_{2} \mathrm{PO}_{4}$ and $\mathrm{Na}_{2} \mathrm{HPO}_{4}$ in the production of $\mathrm{H}_{2}$ using anaerobic sludge as an inoculum and sucrose as a substrate. The results suggest an advantage in replacing the carbonate by a phosphate in the form of $\mathrm{Na}_{2} \mathrm{HPO}_{4}$ as a buffering agent, and the optimal concentration is still $600 \mathrm{mg} / \mathrm{L}$.

Another parameter commonly highlighted as important in anaerobic fermentation processes is the carbon/nitrogen ratio $(\mathrm{C} / \mathrm{N})$. In this respect, $\mathrm{LIN} \&$ LAY (2004) evaluated the production of $\mathrm{H}_{2}$ under different carbon/nitrogen ratios (ranging from 40 to 130) with carbon concentrations between 6.1-
26,5 g COD/L. In these studies, the concentrations of carbon included both the concentrations of COD sewage sludge $(5.2 \mathrm{~g} / \mathrm{L})$ as well as the added sucrose solution. The best results were obtained for the $\mathrm{C} / \mathrm{N}$ ratio equal to 47 , producing $4.8 \mathrm{~mol} \mathrm{H}_{2}$ / mol sucrose in a continuous reactor with complete mixing using mixed cultures of domestic sewage sludge and the bacterium Clostridium pasteurianum.

\subsection{3 $\mathrm{pH}$}

Changes in $\mathrm{pH}$ influence the metabolic activity of bacteria producing $\mathrm{H}_{2}$ and the fermentative process in general because $\mathrm{pH}$ affects the activity of the hydrogenase enzyme as well as the metabolic routes. The metabolic pathways for the production of $\mathrm{H} 2$ cause a decrease in $\mathrm{pH}$ during the exponential growth phase of the bacteria, (DING et al., 2008; FERNANDES, 2008; PATTRA et al., 2008; ROSSI et al., 2011) clearly indicating the acidogenic nature of microbiological activity. This drop in $\mathrm{pH}$ is important because the lower $\mathrm{pH}$ helps in the reduction of methanogenesis. The metabolism of microorganisms changes in the stationary phase. In the exponential phase, the carbohydrates and organic acids are converted to alcohols, such as 1-butanol. As a result of the consumption of acids, the $\mathrm{pH}$ of the medium becomes alkaline. Eventually, the concentrations of alcohols reach levels as high as possible, that can inhibit the activities of the bacteria and ceasing its metabolism.

Finally, on the ideal $\mathrm{pH}$ for the production of $\mathrm{H} 2$, the majority of studies describe a range between 4 and 7 (LIN et al., 2012; MONCIVAIS et al., 2007). This $\mathrm{pH}$ range depends on, for example, the type of culture used in the fermentation process. As an example, TREVISAN (2014) developed an experiment with a mixed culture containing 2.5 $\mathrm{g} / \mathrm{L}$ total volatile solids, and observed that the $\mathrm{pH}$ dramatically affected the production of $\mathrm{H} 2$. The specific hydrogenic activity decreased $95 \%$ when the value of the initial $\mathrm{pH}$ (5.5) was adjusted to 6.0. In the same work, values lower than 5.5 or higher than 6.0 inhibited the action of microorganism producers of H2 (TREVISAN, 2014). However, Choi et al. (2014) showed that the hydrogen produced in this process should be released rapidly from the reactor before other biochemical reactions can consume the hydrogen, and substrates at a high $\mathrm{pH}$ level $(\geq 9.0)$ can be used to produce hydrogen without needing to adjust the $\mathrm{pH}$. 


\subsubsection{Partial Pressure}

When the partial pressure of $\mathrm{H}_{2}$ is relatively low $\left(10^{-4} \mathrm{~atm}\right)$ (GRADY et al., 2011), NADH can be oxidized by hydrogenase, producing $\mathrm{H}_{2}$ at a maximum yield of $4 \mathrm{~mol} / \mathrm{mol}$ hexose consumed and a maximum yield of ATP. However, in normal conditions most $\mathrm{NADH}$ will be oxidized producing reduced final products such as butyrate, which represent a lower molar yield of hydrogen and low yields of ATP. In other studies, KRAEMER \& BAGLEY (2006) and CLARK et al. (2012) affirmed that the reduction of the pressure of $\mathrm{H}_{2}$ in the liquid medium, for example, by sprinkling of $\mathrm{N}_{2}$, is important because the concentrations of dissolved $\mathrm{H}_{2}$ and $\mathrm{CO}_{2}$ decreased, reducing the substrate available for acetogenic, as well as methanogenic, bacteria to consume $\mathrm{H}_{2}$. In this way, a drop in the production of $\mathrm{H}_{2}$ is prevented.

In addition to sprinkling $\mathrm{N}_{2}$, other ways to reduce the partial pressure of $\mathrm{H}_{2}$ in liquid medium include: agitation of the liquid medium (CLARK et al., 2012), adoption of negative pressure in the system (MANDAL et al., 2006) and recirculation of effluent (SCHNITZHOFER et al., 2007).

\subsubsection{Temperature}

Temperature is another important factor in the production of $\mathrm{H}_{2}$ and is related to the speed of biochemical reactions in anaerobic fermentation and, consequently, dissolution of the reagents in the culture medium. For effluent containing biodegraded organic matter, the effect of temperature is not large, however, when the effluent is composed of particulate organic matter, organic compounds or complexes, the effect of temperature on hydrolysis and acidogenesis becomes a concern. Low temperatures require a larger hydraulic detention time for the stabilization of solid biodegradable substances when compared to higher temperatures (GRADY et al., 2011).

An optimal temperature for the production of $\mathrm{H}_{2}$ has not yet been defined, although some studies describe the range among 26 to $40^{\circ} \mathrm{C}$ (MONCIVAIS et al., 2007; MANGAYIL et al., 2012; GARCIA et al., 2012). The best temperature for the process, as well as the best $\mathrm{pH}$, depends on the type of culture present in the reactor. It has been demonstrated that increasing temperature could increase the ability of hydrogen-producing bacteria to produce hydrogen during fermentative, but temperature at much higher levels could decrease it with increasing levels (WANG \& WAN, 2009).
In accordance with the type of culture of microorganisms, the production of $\mathrm{H}_{2}$ can be performed in four schemes: room temperature (15$\left.30^{\circ} \mathrm{C}\right)$; mesophilic $\left(30-39^{\circ} \mathrm{C}\right)$; thermophilic $\left(50-64^{\circ} \mathrm{C}\right)$ and hyper-thermophilic $\left(>65^{\circ} \mathrm{C}\right)$ (LEE et al., 2011).

\subsubsection{Configurations of reactors and modes of operation}

The fermentative process for obtaining $\mathrm{H}_{2}$ can be carried out in a batch or continuous mode. According to Hallenbeck \& Ghosh (2009), the continuous mode of operation tends to be more efficient in the production of $\mathrm{H}_{2}$, which is the most commonly accepted mode in industry.

In relation to the reactors, several settings are applied in the production of $\mathrm{H}_{2}$, among which several reactors stand out: simple batch reactors; FBR - fluidized bed reactor; MBR - membrane bioreactor; CSTR - continuous stirred tank reactor; ASBR- anaerobic sequencing batch reactor; UASB- upflow anaerobic sludge blanket, and each of these reactors has advantages and disadvantages. In addition to these reactors, three other types of reactors for high rates were developed: CSABR- Continuous stirred anaerobic bioreactor (WU et al., 2006), CIGSBR - Carrier induced granular sludge bed reactor (LEE et al., 2004; LEE et al., 2006) and the AGSBR - Agitated granular sludge bed reactor (LIN and LAY, 2010).

Reactors with suspended biomass, as in the CSTR, generally are not capable of operating with high dilution rates (hydraulic detention time $<2$ h), due to the risk of "washing" the microorganisms from the system, compromising the efficiency of the production of $\mathrm{H}_{2}$ (LIN and LAY, 2010). Lin and Lay (2010) recommend the use of the reactor type CSABR, which produced $\mathrm{H}_{2}$ efficiently with a peak of $362 \mathrm{~L}$.L- ${ }^{1} . \mathrm{d}-{ }^{1}$ and yield of $3.5 \mathrm{~mol} \mathrm{H}_{2} / \mathrm{mol}$ sucrose with a hydraulic detention time of $0.5 \mathrm{~h}$ and a high concentration of sucrose $(40 \mathrm{~g} \mathrm{COD} / \mathrm{L})$.

\section{CONCLUSION}

The microbiological production of $\mathrm{H}_{2}$ is a sustainable biotechnological technique that can be used agro-industrial wastes for the fermentation and ensures the production of low-cost energy. Although further studies are needed on the costbenefit profile of this technique, the identification of microorganisms and the improvement of cultivation 
conditions are the first steps for a program to optimize the production of $\mathrm{H}_{2}$ through genetic approaches. In addition, due to its complexity, this process depends on several factors that confound the notation of optimum conditions, requiring the researcher to possess detailed knowledge of the metabolic pathways involved, the type and the concentration of microorganisms present in the fermentation, and the nutritional characteristics of each substrate, as well as the inter-relationships between each of the factors presented in this article. Thus, in practice the organic production of $\mathrm{H}_{2}$ using different substrates and microbial cultures should require operating conditions that may vary significantly. However, the major concern in relation to the production of $\mathrm{H}_{2}$ via microbiological techniques is obtaining processes that reliably transfer to industrial scale and generate a constant amount of $\mathrm{H}_{2}$. For this reason, further studies need to investigate the organic production of $\mathrm{H}_{2}$ from different substrates, wastes and microorganisms to find an ideal technique that can be used for commercial purposes.

\section{ACKNOWLEDGEMENTS}

The Petrobras by financial support for this work and the University of Caxias do Sul.

\section{REFERENCES}

ABDALLAH, R.; DJELAL, H.; AMRANE, A.; SAYED, W.; FOUCAD, F.; LABASQUE, T.; GENESTE, F.; TAHA, S.; FLONER, D. Dark fermentative hydrogen production by anaerobic sludge growing on glucose and ammonium resulting from nitrate eletroreduction. International Journal of Hydrogen Energy, 41, 54455455. 2016.

ALSHIYAB, H. ALSHIYAB, H., KALIL, M S., HAMID, A.A., YUSOFF, W.M.W. Effect of add environmental parameters on hydrogen production using $C$. acetobutylicum. Pakistan Journal of Biological Sciences, 11, 2073-2082. 2008.

AMARAL, P.F.F., FERREIRA, T.F., FONTES, G.C., COELHO, M.A.Z. Glycerol valorization: new biotechnological routes. Food and Bioproducts Processing, 87, 179-186. 2009.

ALSHIYAB, H., KALIL, M S., HAMID, A.A., YUSOFF, W.M.W. Trace metal effect on hydrogen production using C. acetobutylicum. Journal of Biological Sciences, 8, 1-9. 2008.
BAI, M.D., CHENG, S.S., CHAO, Y.C. Effects of substrate components online hydrogen fermentation of multiple substrates. Water Science \& Technology, 50, 209-216. 2004.

BECKERS, L., HILIGSMANN, S., HAMILTON, C., MASSET, J., THONART, P. Fermentative hydrogen production by Clostridium butyricum CWBI1009 and Citrobacter freundii CWBI952 in pure and mixed cultures. Biotechnology, Agronomy, Society and Environment, 14, 541-548. 2010.

CHEN, H.W., LEE, A.S., CHANG, J.S. Fermentative hydrogen production and bacterial community structure in high-rate anaerobic bioreactors containing siliconeimmobilized and self-flocculated sludge. Biotechnology and Bioengineering, 93, 934-946. 2006.

CHOI, J., AHN, Y. Characteristics of biohydrogen fermentation from various substrates. International Journal of Hydrogen Energy, 39, 3152-3159. 2014.

CHONG, M.L., SABARATNAM, V., SHIRAI, Y., HASSAN, M.A. Biohydrogen production from biomass and industrial wastes by dark fermentation. International Journal of Hydrogen Energy, 34, 3277-3287. 2009.

CHOOKAEW, T., THONG, S.O., PRASERTSAN, P. Fermentative production of hydrogen and soluble metabolites from crude glycerol of biodiesel plant by the newly isolated thermotolerant Klebsiella pneumonia TR17. International Journal of Hydrogen Energy, 37, 1331413322. 2012.

CLARK, I.C., ZHANG, R.H., UPADHYAYA, S.K. The effect of low pressure and mixer on biological hydrogen production via anaerobic fermentation. International Journal of Hydrogen Energy, 37, 11504-11513. 2012.

CHEN, S.D., SHEU, D.S., CHEN, W.M., LO, Y.C., HUANG, T.I., LIN, C.Y., CHANG, J.S. Dark hydrogen fermentation from hydrolyzed starch treated with recombinant amylase originating from Caldimonastaiwanensis On1. Biotechnology Progress, 23, 1312-1320. 2007.

CHEN, W.H., CHEN, S.Y., KHANAL, S.K., SUNG, S. Kinetic study of biological hydrogen production by anaerobic fermentation. International Journal of Hydrogen Energy, 31, 2170-2178. 2006.

DABROCK, B., BAHL, H., GOTTSCHALK, G. Parameters affecting solvent production by Clostridium pasteurianum. Aplied and Environmental Microbiology, 58, 1233-1239. 1992.

DRAPCHO, C., NHUAN, N., WALKER, T. Biofuels Engineering Process Technology. The Mc Graw-Hill Companies, Inc.. 2008. 
DAS, D., VEZIROGLU, T. N. Advances in biological hydrogen production processes. International Journal of Hydrogen Energy, 33, 6046-6057. 2008.

DING, H.B., LIU, X.Y., STABNIKOVA, O., WANG J.Y. Effect of protein on biohydrogen production from starch of food waste. Water Science Technology, 57, 10311036. 2008.

DUNN, S. Hydrogen futures Toward a sustainable energy system. International Journal of Hydrogen Energy, 27, 235-264. 2002.

FANG, H.P., LIU, H., ZHANG, T. Characterization of the hydrogen-producing granular sludge. Biotechnology and Bioengineering, 78, 44-52. 2002.

GHIMIRE, A.; FRUNZO, L.; PIROZZI, F.; TRABLY, E.; ESCUDIE, R.; LENS, P.N.L.; ESPOSITO, G. A review on dark fermentative biohydrogen production from organic biomass Process parameters and use of byproducts. Appied Energy, 144, 73-95. 2015.

GHIMIRE, A.; SPOSITO, F.; FRUNZO, L.; TRABLY, E.; ESCUDIE, R.; PIROZZI, F.; LENS, P.N.L.; SPOSITO, G. Effects of operational parameters on dark fermentative hydrogen production biodegradable complex waste biomass. Waste Management, 50, 55-64. 2016.

GRADY, C.P.L., DAIGGER, G.T., LIM, H.C. Biological Wastewater Treatment. 3. Ed. Marcel Dekker, New York. 2011.

GUO, L., LI, X.M., BO, X., YANG, Q., ZENG, G.M., LIAO, D.X., LIU, J.J. Impacts of sterilization, microwaves and ultrasonication pretreatment on hydrogen producing using waste sludge. Bioresource Technology, 99, 36513658. 2008.

GUO, W.Q., REN, N.Q., WANG, X.J., XIANG, W.S., DING, J., YOU, Y., LIU, B.F. Optimization of culture conditions for hydrogen production by Ethanoligenens harbinense B49 using response surface methodology. Bioresource Technology, 100, 1192-1196. 2009.

HALLENBECK, P.C., ABO-HASHESH, M., GOSH, D. Strategies for improving biological hydrogen production. Bioresource Technology, 110, 1-9. 2012.

HALLENBECK, P.C., GHOSH, D. Advances in fermentative biohydrogen production the way forward? Trends in Biotechnology, 27, 287-297. 2009.

HAN, W., WANG, Z., CHEN, H., YAO, X., LI, Y. Simultaneous biohydrogen and bioethanol production from anaerobic fermentation with immobilized sludge. Journal of Biomedicine and Biotechnology, 2011, 1-5. 2011.

HARUN, I., JAHIM, J.M. ANUAR, N., HASSAN,
O. Hydrogen production performance by Enterobacter cloacae $\mathrm{KBH} 3$ isolated from termite guts. International Journal of Hydrogen Energy, 37, 15052-15061. 2012.

HAWKES, F.R., HUSSY, I., KYAZZE, G., DINSDALE, R., HAWKES, D.L. Continuous dark fermentative hydrogen production by mesophilic microflora Principles and progress. International Journal of Hydrogen Energy, 32, 172-184. 2007.

HERBERT, H.P., FANG, H.L. Effect of $\mathrm{pH}$ on hydrogen production from glucose by the mixed culture. Bioresource Technology, 82, 87-93. 2002.

HO, K.L., LEE, D.J. Harvesting biohydrogen form cellobiose from sulfide or nitrite- containing wastewaters using Clostridium sp. R1. Bioresource Technology, 102, 8547-8549. 2011.

ITO, T., NAKASHIMADA, Y., SENBA, K., MATSUI, T., NISHIO, N. Hydrogen and ethanol production from glycerol-containing wastes discharged after biodiesel manufacturing process. Journal of Bioscience and Bioengineering, 100, 260-265. 2005.

JITRWUNG, R., VERRETT, J., YARGEAU, V. Optimization of selected salts concentration is improved biohydrogen production from bio-based glycerol using Enterobacter aerogenes. Renewable Energy, 50, 222226. 2013.

JITRWUNG, R., YARGEAU, V. Optimization of medium composition for the production of biohydrogen from waste glycerol. International Journal of Hydrogen Energy, 36, 9602-9611. 2011.

JUNYAPOON, S., BUALA, W., PHUNPRUCH, S. Hydrogen Production with Escherichia coli isolated from municipal sewage sludge. Thammasat Int. J. Sc. Tech., 16, 9-15. 2011.

KALINCI, Y., HEPBASLI, A., DINCER, I. Biomassbased production A review and analysis. International Journal of Hydrogen Energy, 34, 8799-8817. 2009.

KAPDAN, I., KARGI, F. Bio-hydrogen production from waste materials. Enzyme and Microbial Technology, 38, 569-582. 2006.

KAWAGOSHI, Y., HINO, N., FUJIMOTO, A., NAKAO, M., FUJITA, Y., SUGIMURA, S., FURUKAWA, K. Effect of inoculum conditioning on hydrogen fermentation and $\mathrm{pH}$ effect on bacterial community relevant to hydrogen production. Journal of Bioscience and Bioengineering, 100, 524-530. 2005.

KHANAL, S.K., CHEN, W.H., LI, L., SUNG, S. Biological hydrogen production effects of $\mathrm{pH}$ and intermediate products. International Journal of Hydrogen Energy 29, 1123-1131 . 2004. 
KHANNA, N., KOTAY, S.M., GILBERT,J.J., DAS, D. Improvement of biohydrogen production by Enterobacter cloacae II T-BT 08 under regulated $\mathrm{pH}$. Journal of Biotechnology, 152, 9-15. 2011.

KIM, S.H., SHIN, H.S. Effects of base-pretreatment on continuous enriched culture for hydrogen production from food waste. International Journal of Hydrogen Energy, 33, 5266-5274. 2008.

KRAEMER, J.T., BAGLEY, D.M. Supersaturation of dissolved $\mathrm{H}_{2}$ and $\mathrm{CO}_{2}$ during fermentative hydrogen production with $\mathrm{N}_{2}$ sparging. Biotechnology Letters, 28, 1485-1491. 2006.

KRAEMER, J.T., BAGLEY, D. M. Optimisation and design of nitrogen-sparged fermentative hydrogen production bioreactors. International Journal of Hydrogen Energy 33, 6558-6565. 2008a.

KRAEMER, J.T., BAGLEY, D.M., Measurement of $\mathrm{H}_{2}$ consumption and its role in continuous fermentative hydrogen production. Water Science Technology, 57, 681-685. 2008b.

KOTAY, S., DAS, D. Biohydrogen as the renewable energy resource - Prospects and potencials. International Journal of Hydrogen Energy, 33, 258-263. 2008.

KUROKAWA, T., TANISHO, S. Effects of format on fermentative hydrogen production by Enterobacter aerogenes. Marine Biotechnology, 7, 112-118. 2005.

KUMAR, N., GHOSH, A., DAS, D. Redirection of biochemical pathways is the enhancement of $\mathrm{H}_{2}$ production by Enterobacter cloacae. Biotechnology Letters, 23, 537541. 2001.

KUMAR, G.; BAKONYI, P.; KOBAYASHI, T.; XU, K.; SIVAGURUNATHAN, P.; KIM, S.; BUITRON, G.; NEMESTOTHY, N.; BAKO, K. Enhancement of biofuel production via microbial augmentation The case of dark fermentative hydrogen. Renewable and Sustainable Energy Reviews, 57, 879-891. 2016.

KUO, S.C., CHAO, Y.C., TIEN, Y.M., CHEN, I.C., CHENG, S.S. Bio-hydrogen behavior of suspended and attached microorganisms in anaerobic fluidized bed. International Journal of Hydrogen Energy, 36, 88008808. 2011.

LAKSHMIDEVI, R., MUTHUKUMAR, K. Enzymatic saccharification and fermentation of paper and pulp industry effluent for biohydrogen production. International Journal of Hydrogen Energy, 35, 33893400. 2010.

LAZARO, C.Z., PERNA, V., ETCHEBEHERE, C., VARESCH, M.B.A. Sugarcane vinasse as substrate for fermentative hydrogen production: The effects of temperature and substrate concentration. International Journal of Hydrogen Energy, 39, 6407-6418. 2014.

LAY, C.H., WU, J.H., HSIAO, C.L., CHANG, J.J., CHEN, C.C., LIN, C.Y. Biohydrogen production from soluble condensed molasses fermentation using anaerobic fermentation. International Journal of Hydrogen Energy, 35, 13445-13451. 2010.

LEE, D.J., SHOW, K.Y., SU, A. Dark fermentation on biohydrogen production Pure culture. Bioresource Technology, 102, 8393-8402. 2011.

LEE, K.S., LO, Y.C., LIN, P.J., CHANG, J.S. Improving biohydrogen production in a carrier-induced granular sludge bed by altering physical configuration and agitation pattern of the bioreactor. International Journal of Hydrogen Energy, 31, 1648-1657. 2006.

LEE, Y.J., MIYAHARA, T., NOIKE, T. Effect of iron concentration on hydrogen fermentation. Bioresource Technology, 80, 227-231. 2001.

LEE, K.S., HSU, Y.F., LO, Y.C., LIN, P.J., LIN, C.Y., CHANG, J.S. Exploring optimal environmental factors is fermentative hydrogen production from starch using mixed anaerobic microflora. International Journal of Hydrogen Energy, 33, 1565-1572. 2008.

LEVIN, D.B., PITT, L., LOVE, M. Biohydrogen production prospects and limitations to practical application. International Journal of Hydrogen Energy, 29, 173-185. 2004.

LEVIN, D.B., ISLAM, R., CICEK, N., SPARLING, R. Hydrogen production by Clostridium thermocellum 27405 from cellulosic biomass substrates. International Journal of Hydrogen Energy, 31, 1496-1503. 2006.

LIMA, D.M.F., ZAIAT, M. The influence of the degree of back-mixing on hydrogen production in an anaerobic fixed-bed reactor. International Journal of Hydrogen Energy 37, 9630-9635 . 2012.

LIU, F., FANG, B. Optimization of biohydrogen production from biodiesel wastes by Klebsiella pneumoniae. Biotechnology Journal, 2, 374-380. 2007.

LIN, C.Y., CHENG, C.H. Fermentative hydrogen production from xylose using anaerobic mixed microflora. International Journal of Hydrogen Energy, 31, 832-840. 2006.

LIN, C.Y., LAY, C.H., SEN, B., CHU, C.Y., KUMAR, G., CHEN, C.C., CHANG, J.S. Fermentative hydrogen production from wastewaters a review and prognosis. International Journal of Hydrogen Energy, 37, 15632-15642. 2012.

LIN, C.Y., LAY, C.H., Research and development of biohydrogen production in Taiwan. In Fang, H.H.P. 
(Org.). Environmental anaerobic technology applications and new developments, pp.331-244. London Imperial College Press, London. 2010.

LIN, C.Y., LAY, C.H. Effects of carbonate and phosphate concentrations on hydrogen production using anaerobic sewage sludge microflora. International Journal of Hydrogen Energy, 29, 275-281. 2004.

LIN, C.Y., LAY, C.H. A nutrient formulation for fermentative hydrogen production using anaerobic sewage sludge microflora. International Journal of Hydrogen Energy, 30, 285-292. 2005.

LIN, C.Y., CHANG, R.C. Fermentative hydrogen production at ambient temperature. International Journal of Hydrogen Energy, 29, 715-720. 2004.

LI, S., LAI, C., CAI, Y., YANG, X., YANG, S., ZHU, M., WANG, J., WANG, X. High efficiency hydrogen production from glucose/xylose by the ldh-deleted Thermoanaerobacterium strain. Bioresource Technology, 101, 8718-8724. 2010.

LU, Y., ZHAO, H., ZHANG, C., LAI, Q., XING, X. Perturbation of formate pathway for hydrogen production by expressions of formate hydrogen lyase and its transcriptional activator in wild Enterobacter aerogenes and its mutants. International Journal of Hydrogen Energy, 34, 5072-5079. 2009.

LU, Y., ZHANG, C., LAI, Q., ZHAO, H., XING, X.H. Improved hydrogen production under microaerophilic conditions by overexpression of polyphosphate kinase in Enterobacter aerogenes. Enzyme and Microbial Technology, 48, 187-192. 2011.

LOGAN, B.E., OH, S.E., KIM, I.S., VAN GINKEL, S. Biological hydrogen production measured in batch anaerobic respirometers. Environmental Science and Technology, 36, 2530-2535. 2002.

LO, Y.C., CHEN, W.M., HUNG, C.H., CHEN, S.D., CHANG, J.S. Dark $\mathrm{H}_{2}$ fermentation from sucrose and xylose using $\mathrm{H}_{2}$-producing indigenous bacteria feasibility and kinetic studies. Water Research, 42, 827-842. 2008.

MAINTINGUER, S.I., FERNANDES, B.S., DUARTE, I.C.S., SAAVEDRA, N.K., ADORNO, M.A.T., VARESCHE, M.B. Fermentative hydrogen production by microbial consortium. International Journal of Hydrogen Energy, 33, 4309-4317. 2008.

MAINTINGUER, S.I., SAKAMOTO, I.K.; ADORNO, M.A.T., VARESCHE, M.B.A. Evaluation of the microbial diversity of denitrifying bacteria in batch reactor. Brazilian Journal Chemical Engineering, 30, 457-465. 2013.

MAINTINGUER, S.I., SAKAMOTO, I.K.; ADORNO, M.A.T., VARESCHE, M.B.A. Bacterial diversity from environmental sample applied to bio-hydrogen production. International Journal of Hydrogen Energy, 40, 3180-3190. 2015.

MANDAL, B., NATH, K., DAS, D. Improvement of biohydrogen production under decreased partial pressure of $\mathrm{H}_{2}$ by Enterobacter cloacae. Biotechnology Letters, 28, 831-835. 2006.

MANGAYIL, R., KARP, M., SANTALA, V. Bioconversion of crude glycerol from biodiesel production to hydrogen. International Journal of Hydrogen Energy, 37, 1219812203. 2012.

MARKOV, S.A., AVERITT, J., WALDRON, B. Bioreactor for glycerol conversion into $\mathrm{H} 2$ by bacterium Enterobacter aerogenes. International Journal of Hydrogen Energy, 36, 262-266. 2011.

MARTINEZ-PEREZ， N., CHERRYMAN, S.J., PREMIER, G.C., DINSDALE, R.M., HAWKES, D.L., HAWKES, F.R., KYAZZE, G., GUWY, A.J. The potential for hydrogen-enriched biogas production from crops Scenarios in the UK. Biomass and Bioenergy Journal, 31, 95-104 . 2007.

MATSUNAGA, T., HATANO, T., YAMADA, A., MATSUMOTO, M. Microaerobic hydrogen production by photosynthetic bacteria in a double-phase photobiorreator. Biotechnology Bioengineering, 68, 647-651. 2000.

MONCIVAIS, A.M., MORENO, G., BUITRON, $\mathrm{G}$. Influence of inoculum source, $\mathrm{pH}$ and temperature on hydrogen production. In IWA World Congress on Anaerobic Digestion, Brisbane, 11. 2007.

MOHAN, S.V., BABU, V.L., SARMA, P.N. Effect of various pretreatment methods on anaerobic mixed microflora to enhance biohydrogen production utilizing dairy wastewater as substrate. Bioresource Technology, 99, 59-67. 2008.

NAKASHIMADA, Y., RACHMAN, M.A., KAKIZONO, T., NISHIO, N. Hydrogen production of Enterobacter aerogenes altered by extracellular and intracellular redox states. International Journal of Hydrogen Energy, 27, 1399-1405. 2002.

NIU, K., ZHANG, X., TAN, W.S., ZHU, M.L. Characteristics of fermentative hydrogen production with Klebsiella pneumoniae ECU-15 isolated from anaerobic sewage sludge. International Journal of Hydrogen Energy, 35, 71-80. 2010.

NGO, T., YES, S.J. Dark fermentation of hydrogen from waste glycerol using hyperthermophilic Eubacterium Thermotoganeapolitana. Environmental Progress \& Sustainable Energy, 31, 466-473. 2012. 
NOORI M., SAADY, C. Homoacetogenesis during hydrogen production by cultures dark fermentation Unresolved challenge. International Journal of Hydrogen Energy, 38, 13172-13191. 2013.

OH, Y.K., KIM, H.J., PARK, S., KIM, M.S., RYU, D.D.Y. Metabolic-flux analysis of hydrogen production pathway in Citrobacter amalonaticus Y19. International Journal of Hydrogen Energy, 33, 1471-1482. 2008.

OH, A.E., YI, Z., ZHANG, H., MARK, J.G., LOGAN, B.E., REGAN, J.M. Hydrogen production by Clostridium acetobutylicum ATCC 824 and megaplasmid-deficient mutant M5 evaluated using a large headspace volume technique. International Journal of Hydrogen Energy, 3, 9347-9353. 2009.

OH, Y.K., SEOL, E.H., LEE, E.Y., PARK, S. Fermentative hydrogen production by a new

chemoheterotrophic bacterium Rhodopseudomonas palustris P4. International Journal of Hydrogen Energy, 27, 1373-1379. 2002.

QIAN, C.X., CHEN, L.Y., RONG, H., YUAN, X.M. Hydrogen production by mixed culture of several facultative bacteria and anaerobic bacteria. Progress in Natural Science Materials International, 21, 506-511. 2011.

OLIVEIRA, L.L., COSTA, R.B., SAKAMOTO, I.K., DUARTE, I.C.S., SILVA, E.L., VRESCHE, M.B. Las degradation in a fluidized bed reactor and phylogenetic characterization of the biofilm. Brazilian Journal Chemical Engineering,30, 521-529. 2013.

PAN, C.M., FAN, Y.T., XING, Y., HOU, H.W., ZHANG, M.L. Statistical optimization of process parameters on biohydrogen production from glucose by Clostridium sp. Fanp2. Bioresource Technology, 99, 3146-3154. 2008.

PANDU, K., JOSEPH, S. Comparisons and limitations of biohydrogen production processes a review. International Journal of Advances in Engineering \& Technology, 2, 342-356. 2012.

PATTRA, S., SANGYOKA, S., BOONMEE, M., REUNGSANG, A. Bio-hydrogen production from the fermentation of sugarcane bagasse hydrolysate by Clostridium butyricum. International Journal of Hydrogen Energy, 33, 5256-5265. 2008.

PHOWAN, P., REUNGSANG, A., DANVIRUTAI, P. Bio-hydrogen Production from Cassava Pulp Hydrolysate using Co-culture of Clostridium and Enterobacter aerogenes. Biotechnology, 9, 348-354. 2010.

PEIXOTO, G. Produção de hidrogênio em reator anaeróbio de leito fixo e fluxo ascendente a partir de água residuária de indústria de refrigerantes. Ph.D. Thesis, University of Sáo Paulo. 2008.
POLETO, L., SOUZA, P., MAGRINI, F.E., BEAL, L.L., TORRES, A.P.R., SOUSA, M.P., LAURINO, J.P., PAESI, S. Selection and identification of microorganisms present in the treatment of wastewater and activated sludge to produce biohydrogen from glycerol. International Journal of Hydrogen Energy, 41, 4374-4381. 2016.

ROSSI, D.M., COSTA, J.B., SOUZA, E.A. PERALBA, M.C.R., SAMIOS, D., AYUB, M.A. Z. Comparison of different pretreatment methods for hydrogenproduction using environmental microbial consortia on residual glycerol from biodiesel. International Journal of Hydrogen Energy, 36, 4814-4819. 2011.

SAINT-AMANS, S., GIRBAL, L., ANDRADE, J., AHRENS K., SOUCAILLE, P. Regulation of carbon and electron flow in Clostridium butyricum VPI3266 grown on glucose-glycerol mixtures. Journal of Bacteriology, 183, 1748-1754. 2001.

SALVI, B.L.; SUBRAMANIAN, K.A. Sustainable development of road transposrtation sector hydrogen energy system. Renewable and Sustainable Energy Review, 51, 1132-1155. 2015.

SAWYER, C.N., MCCARTY, P.L., PARKIN, G.F. Chemistry for Environmental Engineering. 4. Ed. Mc Graw-Hill, New York. 1994.

SINHA, P., PANDEY, A. An evaluative report and challenges for fermentative biohydrogen production. International Journal of Hydrogen Energy, 36, 7460-7478. 2011.

SIQUEIRA, M.R.; REGINATTO, V. Inhibition of fermentative $\mathrm{H}_{2}$ production by hydrolysis by products of lignocellulosic substrates. Renewable Energy, 80, 109116. 2015.

SCHNITZHOFER, W., SCHUHMACHER, M., SCHÖNHERR, F., MODIGELL, M., DE VRIJE T., CLAASSEN P.A.M. Non-thermal production of hydrogen from biomass Concept and bioprocess development. In IWA World Congress on Anaerobic Digestion, Brisbane, 11. 2007.

SHOW, K.Y., LEE, D.J., TAY, J.H., LIN, C.Y., CHANG, J.S. Biohydrogen production current perspectives and the way forward. International Journal of Hydrogen Energy, 37, 15616-15631. 2012.

SITTIJUNDA, S., REUNGSANG, A. Biohydrogen production from waste glycerol and sludge by anaerobic mixed cultures. International Journal of Hydrogen Energy, 37, 13789-13796. 2012.

SONG, L., DONG, X. Clostridium amylolyticum sp. nov., isolated from $\mathrm{H}_{2}$-producing UASB granules. International Journal of Systematic and will make an evolutionary Microbiology, 58, 2132-2135. 2008. 
SUN, Q., XIAO, W., XI, D., SHI, J., YAN, X., ZHOU, Z. Statistical optimization of biohydrogen production from sucrose by a co-culture of Clostridium acidisoli and Rhodobactersphaeroides. International Journal of Hydrogen Energy, 35, 4076-4084. 2010.

SUHAIMI, S.N., PHANG, L.Y., MAEDA, T., ABDAZIZ, S., WAKISAKA, M., SHIRAI, Y., HASSAN, M.A. Bioconversion of glycerol for bioethanol production using isolated Escherichia coli SS1. Brazilian Journal of Microbiology, 43, 506-516. 2012.

SYDNEY, E.B., LARROCHE, C., NOVAK, A.C., NOUAILLE, R., SARMA, S.J., BRAR, S.K., LETTI, L.A.J., SOCCOL, V. T., SOCCOL, C.R. Economic process to produce biohydrogen and volatile fatty acids by a mixed culture using vinasse from sugarcane ethanol industry as nutrient source. Bioresource Technology, 159, 380-386. 2014.

TANSKSALE, A., BELTRAMINI, J.N., LU, G.M.A. Review of Catalytic Hydrogen Production Processes from Biomass. Renewable and Sustainable Energy Reviews, 14, 166-182. 2010.

TREVISAN, V., MONTEGGIA L.O., DELABARY, H.S. A short-term test for the evaluation of hydrogen and volatile fatty acids production from industrial effluents. International Journal of Hydrogen Energy, 39, 77307734. 2014.

TOLVANEN, K.E.S., KARP, M.T. Molecular methods for characterizing mixed microbial communities in hydrogenfermenting systems. International Journal of Hydrogen Energy, 36, 5280-5288. 2011.

TUS'AK, S., HAVRLAND, B., MUÑOZ, J.O.J., FERNÁNDEZ, E.C., LACHMAN, J. Experimental verification of various methods for biological hydrogen production. International Journal of Hydrogen Energy, 32, 1736-1741. 2007.

VALDEZ-VAZQUEZ, I., POGGIO-VARALDO, H.M. Hydrogen production by fermentative consortia. Renewable and Sustainable Energy Reviews, 13, 10001013. 2009.

WANG, R., ZONG, W., QIAN, C., WEI, Y., YU, R., ZHOU, Z. Isolation of Clostridium perfringens strain W 11 and optimization of its biohydrogen production by genetic modification. International Journal of Hydrogen Energy, 36, 12159-12167. 2011.

WANG, J., WAN, W. Effect of temperature on fermentative hydrogen production by mixed cultures. International Journal of Hydrogen Energy, 33, 5392-5397. 2008.

WANG, J., WAN, W. Factors influencing fermentative hydrogen production A review. International Journal of Hydrogen Energy, 34, 799-811. 2009.
WANG, M., WANG, Z., GUO Z. Water electrolysis enhanced by super gravity field for hydrogen production. International Journal of Hydrogen Energy, 35, 3198-3205. 2010.

WU, K.J, GANESH, S.D., LO, Y.C., CHEN, W.M., TSENG, Z.J., CHANG, M.C., TSAI, B.C., SUD, A., CHANG, J.S. Simultaneous production of 2,3-butanediol, ethanol and hydrogen with a Klebsiella sp. strain isolated from sewage sludge. Bioresource Technology, 99, 79667970. 2008.

WU, S.Y., HUNG, C.H., LIN, C.N., LU, Y., ZHAO, H., ZHANG, C., LAI, Q., X, W., XING, X.H. Alteration of hydrogen metabolism of ldh-deleted Enterobacter aerogenes by overexpression of NAD (+) - dependent formate dehydrogenase. Applied Microbiology and Biotechnology, 86, 255 -262. 2010.

XIAO, B., HAN; Y., LIU, J. Evaluation of biohydrogen production from glucose and protein at neutral initial $\mathrm{pH}$. International Journal of Hydrogen Energy, 35, 61526160. 2010.

YASIN, N.H.M.; MUMTAZ, T.; HASSAN, M.A.; RAHMAN, N.A. Food waste and food processing waste for biohydrogen production A review. Journal of Environmental Management, 130, 375-385. 2013.

YAZDANI, S.S., GONZALEZ, R. Anaerobic fermentation of glycerol a path to economic viability for the biofuels industry. Current Opinion Biotechnology, 8, 213-219. 2007.

ZHANG, C., FX, LV., XING, X.H. Bioengineering of the Enterobacter aerogenes strain for biohydrogen production. Bioresource Technology, 102, 8344-8349. 2011.

ZHANG, H., BRUNS, M.A., LOGAN, B.E. Biological hydrogen production by Clostridium acetobutyricum in an unsaturated flow reactor. Water Research, 40, 728-734. 2006.

ZHAO, H., MA, K., LU, Y., ZHANG, C., WANG, L., XING, X.H. Cloning and knockout of formate hydrogen lyase and $\mathrm{H}_{2}$-uptake hydrogenase genes in Enterobacter aerogenes for enhanced hydrogen production. International Journal of Hydrogen Energy, 34, 186-194. 2009.

ZHU, H., BÉLAND, M. Evaluation of alternative methods of preparing hydrogen producing seeds from digested wastewater sludge. International Journal of Hydrogen Energy, 31, 1980 -1988. 2006. 